\title{
KARAKTERISTIK KETERAMPILAN BERPIKIR KREATIF DALAM PEMECAHAN MASALAH FISIKA BERDASARKAN GENDER
}

\author{
Mochammad Maulana Trianggono $^{\mathbf{1}}$, Setyaningsih Yuanita ${ }^{1}$ \\ ${ }^{1}$ IKIP PGRI Jember, Jember 68121, Indonesia \\ Email:_maulanatri@ikipjember.ac.id; nea_cutee@yahoo.com
}

Received: 1308 2018. Revised: 2109 2018. Accepted: 29092018

\begin{abstract}
Abstrak
Setiap orang memiliki potensi kreatif yang berbeda-beda. Perbedaan tersebut dapat dipengaruhi oleh pengalaman, pola berpikir, cara menentukan sudut pandang, dan faktor-faktor lainnya. Penelitian ini bertujuan untuk mendeskripsikan perbedaan karakteristik keterampilan berpikir kreatif antara laki-laki dan perempuan dalam konteks pemecahan masalah fisika. Subjek yang diteliti adalah mahasiswa berusia antara 18-20 Tahun yang terdiri dari 5 laki-laki dan 5 perempuan. Perbedaan karakteristik keterampilan berpikir kreatif tersebut dianalisis secara kuantitatif menggunakan uji-t dan secara deskriptif berdasarkan hasil observasi pada pola jawaban dalam tes uraian. Berdasarkan hasil analisis uji-t antara keterampilan berpikir kreatif laki-laki dan perempuan, secara umum tidak terdapat perbedaan yang signifikan antara keduanya dengan $t_{\text {hitung }}(0,75)<\mathrm{t}_{\text {tabel }}(1,86)$. Perbedaan karakteristik keterampilan berpikir kreatif baru terlihat pada indikator keterampilan berpikir kreatif, yakni pada indikator fluency, flexibility, dan elaboration, sedangkan pada indikator originality tidak terdapat perbedaan yang signifikan. Perbedaan karakteristik yang terjadi dalam penelitian ini disebabkan oleh perbedaan pola penalaran antara subjek laki-laki dan perempuan dalam memecahkan masalah fisika yang diberikan. Subjek laki-laki cenderung menuangkan banyak ide dan penalaran jawaban yang bervariasi, sedangkan subjek perempuan memiliki kecenderungan untuk merinci secara detail jawaban yang dikemukakannya.
\end{abstract}

Kata Kunci: keterampilan berpikir kreatif; perbedaan gender; pemecahan masalah fisika

\section{CHARACTERISTICS OF CREATIVE THINKING SKILLS IN PHYSICS PROBLEM SOLVING BASED ON GENDER}

\begin{abstract}
Everyone has different creative potential. These differences can be influenced by experience, thinking patterns, points of view, and other factors. This study aims to describe the different characteristics of creative thinking skills between men and women in the context of physics problem solving. The subjects were students aged between 18-20 years consisting of 5 men and 5 women. The differences in the characteristics of creative thinking skills were analyzed quantitatively using t-test and descriptive based on observations on the answer patterns of description test. Based on the results of the t-test analysis between male and female creative thinking skills, generaly, there is no significant difference between them with $t_{\text {count }}$ (0.75) $<t_{\text {table }}(1.86)$. The differences of characteristic are only seen in the indicators of creative thinking skills, namely on the indicators of fluency, flexibility, and elaboration, whereas in the indicator of originality there is no significant difference. The differences in characteristics that occur in this study are caused by differences in reasoning patterns between male and female subjects in solving the given physics problem. Male subjects tend to pour a variety of ideas and various reasoning answers, while female subjects have a tendency to detail the answers.
\end{abstract}

Keywords: Creative thinking skills; gender difference; physics problem solving 


\section{PENDAHULUAN}

Setiap orang memiliki potensi untuk selalu mengembangkan kemampuan berpikirnya. Salah satu potensi yang dimiliki oleh seseorang adalah potensi kreatif. Potensi kreatif yang dimiliki seseorang merupakan dasar untuk mengembangkan kemampuan berpikir kreatif. Setiap orang memiliki potensi dan karakteristik berpikir kreatif yang berbeda-beda. Pada dasarnya, perkembangan kemampuan berpikir kreatif seseorang akan terus berkembang seiring dengan kematangan pola pikir dan struktur kognitif seseorang. Kematangan pola pikir dan struktur kognitif berkaitan dengan pemahaman konsep seseorang terhadap sesuatu. Menurut (Trianggono, 2017) mengatakan bahwa terdapat hubungan konstruktif antara kemampuan berpikir kreatif dengan pemahaman konsep seseorang. Hubungan konstruktif yang terbangun antara kemampuan berpikir kreatif dengan pemahaman konsep dapat menjadi kolaborasi yang baik untuk memecahkan suatu permasalahan.

Dalam konteks pemecahan masalah fisika, setiap orang memiliki pemahaman konsep dan kemampuan berpikir kreatif yang berbeda-beda, sehingga setiap orang akan memberikan solusi kreatif yang berbeda-beda pula terhadap permasalahan yang diberikan. Perbedaan pola kreatif yang terjadi dapat disebabkan oleh pengalaman setiap orang yang berbeda-beda dalam memecahkan suatu permasalahan. Perbedaan tersebut juga dapat disebabkan oleh pola pikir dan sudut pandang yang berbeda-beda dalam menilai suatu permasalahan.

Kreativitas menurut (Al-Oweidi, 2013) adalah serangkaian kemampuan mental yang diarahkan oleh keinginan yang kuat untuk menghasilkan ide, alternatif, atau kemungkinan yang digunakan untuk memecahkan masalah dan berkomunikasi dengan orang lain. Berdasarkan pendapat tersebut, keterampilan berpikir kreatif dapat didefinisikan sebagai kemampuan untuk menggunakan pola pikir kreatif secara alamiah dalam memecahkan suatu permasalahan. Menurut (Guilford, 1967), keterampilan berpikir kreatif terdiri dari aspek kelancaran (fluency), keluwesan (flexibility), orisinalitas (originality), dan elaborasi (elaboration). Setiap orang memiliki kecenderungan yang berbeda pada setiap aspek keterampilan berpikir kreatif. Setiap orang memiliki kecenderungan aspek keterampilan berpikir kreatif yang berbeda dalam pemecahan masalah (Djupanda, Kendek, \& Darmadi, 2015). Siswa yang memiliki skor aspek elaborasi yang tinggi lebih mampu memecahkan masalah fisika yang memuat masalah matematis fisika. Berdasarkan temuan tersebut, maka setiap aspek dalam keterampilan berpikir kreatif memiliki peranan yang berbeda dalam pemecahan masalah sesuai dengan jenis permasalahan yang diberikan.

Beberapa temuan (Ai, 1999; Naderi, Abdullah, Aizan, Sharir, \& Mallan, 2009) menunjukkan bahwa terdapat perbedaan karakteristik kreativitas antara laki-laki dan perempuan, dimana laki-laki unggul terhadap perempuan untuk beberapa aspek kreativitas, tetapi perempuan umumnya juga lebih baik daripada laki-laki di aspek yang lain. (Abraham, Thybusch, Pieritz, \& Hermann, 2014) mengatakan bahwa pada saat berpikir divergen, daerah yang berhubungan dengan memori deklaratif bekerja sangat aktif pada pria, sedangkan daerah yang terlibat dalam teori pikiran dan proses referensi diri lebih banyak terlibat pada wanita. (Abraham, 2016) juga mengatakan bahwa meskipun pria dan wanita memiliki perilaku berpikir kreatif dan divergen yang sebanding, perbedaan aktivitas otak menunjukkan keduanya dapat menggunakan strategi kognitif yang berbeda ketika melakukan tugas-tugas tersebut. Temuan tersebut mengindikasikan bahwa antara laki-laki dan perempuan memiliki perbedaan karakteristik di berbagai aspek keterampilan berpikir kreatif.

Penelitian ini bertujuan untuk mendeskripsikan perbedaan karakteristik keterampilan berpikir kreatif antara laki-laki dan perempuan dalam pemecahan masalah fisika melalui tes uraian terbuka. Pemecahan masalah fisika yang diberikan berupa permasalahan-permasalahan fisika yang membutuhkan pemikiran divergen untuk menyelesaikannya.

\section{METODE}

Penelitian ini merupakan penelitian kuantitatif-deskriptif untuk melihat karakteristik keterampilan berpikir kreatif melalui tes pemecahan masalah fisika. Tujuan penelitian ini adalah untuk 
mendeskripsikan perbedaan karakteristik keterampilan berpikir kreatif antara laki-laki dan perempuan dalam hal pemecahan masalah fisika. Subjek yang diteliti adalah mahasiswa berusia antara 18-20 Tahun yang terdiri dari 5 laki-laki dan 5 perempuan. Mahasiswa yang menjadi subjek merupakan mahasiswa semester I Fakultas P.MIPA IKIP PGRI Jember Tahun Ajaran 2016-2017. Pengambilan data dilakukan dengan cara pemberian tes uraian pemecahan masalah fisika. Instrumen penelitian yang digunakan berupa instrumen evaluasi yang terdiri dari 10 soal pemecahan masalah kreatif.

Data hasil penelitian kemudian dianalisis secara kuantitatif menggunakan uji-t (uji beda) dengan taraf signifikansi 5\% dan secara deskriptif berdasarkan hasil observasi pada pola jawaban dalam tes uraian. Uji beda digunakan untuk menganalisis perbedaan antara karakteristik keterampilan berpikir kreatif subjek laki-laki dengan perempuan, baik secara umum, maupun secara khusus pada masing-masing indikator keterampilan berpikir kreatif (aspek fluency, flexibility, originality, dan elaboration). Hasil analisis tersebut kemudian dijabarkan dan dianalisis secara deskriptif berdasarkan pola jawaban yang diberikan pada tes pemecahan masalah.

\section{HASIL DAN PEMBAHASAN}

\section{Tinjauan Umum Karakteristik Keterampilan Berpikir Kreatif \\ Pemecahan masalah} membutuhkan penalaran yang divergen dalam penyelesaiannya. Masing-masing orang memiliki caranya sendiri dalam memecahkan masalah. Tes pemecahan masalah fisika yang diberikan sejumlah 10 soal yang terdiri dari permasalahan gerak, fluida, suhu dan kalor, energi, dan gelombang. Berdasarkan penelitian yang telah dilakukan, terlihat pada Gambar 1 bahwa baik subjek laki-laki maupun perempuan memiliki skor rata-rata keterampilan berpikir kreatif yang sebanding.

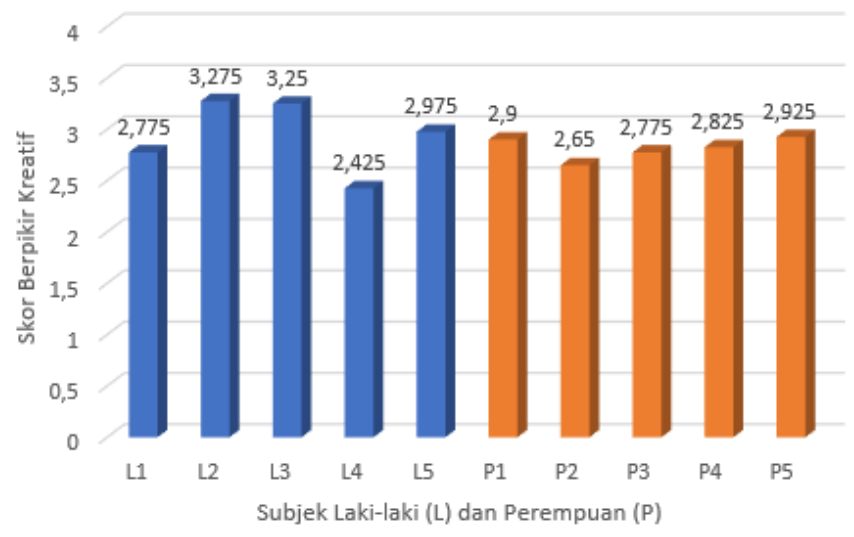

Gambar 1. Grafik Perbandingan Skor Keterampilan Berpikir Kreatif secara Umum

Grafik pada Gambar 1 memperlihatkan bahwa skor rata-rata keterampilan berpikir kreatif antara subjek laki-laki dan perempuan dalam batas yang tidak terlalu jauh, atau dapat dikatakan sebanding. Data skor ratarata keterampilan berpikir kreatif dianalisis menggunakan uji-t dengan taraf signifikansi 5\% disajikan pada Tabel 1 berikut.

Tabel 1. Hasil Analisis Uji-t terhadap Skor Rata-rata Keterampilan Berpikir Kreatif

\begin{tabular}{cll}
\hline No & Analisis & Nilai \\
\hline 1. & Mean $L$ & 2,94 \\
\hline 2. & Mean $P$ & 2,815 \\
\hline 3. & $\mathrm{t}_{\text {stat }}$ & 0,753607107 \\
\hline 4. & $\mathrm{t}_{\text {critical }}$ one-tail & 1,859548038 \\
\hline 5. & $\mathrm{P}(\mathrm{T}<=\mathrm{t})$ one-tail & 0,236339666
\end{tabular}

Hasil analisis uji-t terhadap skor ratarata keterampilan berpikir kreatif antara subjek laki-laki dan perempuan memperlihatkan bahwa harga $t_{\text {hitung }}$ adalah sebesar 0,753607107. Harga $t_{\text {hitung }}$ lebih kecil dibandingkan harga $t_{\text {tabel }}$ sebesar 1,859548038. Terlihat pula harga $\mathrm{P}(\mathrm{T}<=\mathrm{t})$ one-tail sebesar 0,236339666 lebih besar dari 
taraf signifikansi yang diberikan, yakni 0,05. Hasil tersebut menekankan bahwa tidak terdapat perbedaan yang signifikan pada keterampilan berpikir kreatif secara umum antara subjek laki-laki dan perempuan. Skor yang diperoleh merupakan skor rata-rata dari keempat indikator keterampilan berpikir kreatif (fluency, flexibility, originality, dan elaboration), sehingga belum dapat teridentifikasi perbedaan karakteristik keterampilan berpikir kreatif sebagai proses berpikirnya. Hal tersebut dapat dianalogikan seperti dua orang yang memiliki kemampuan berbeda (satu orang pandai matematika, fisika, dan kimia, sedangkan satu orang lainnya pandai bahasa, seni, dan biologi) namun hasil belajar akhir secara umum dapat sebanding (jika dinilai secara rata-rata). Karakteristik keterampilan berpikir kreatif secara umum dapat dikatakan sebanding antara laki-laki dan perempuan, namun belum tentu sama dalam proses berpikir dan pola kreatifnya. Berikut akan dipaparkan perbandingan karakteristik keterampilan berpikir kreatif antara subjek laki-laki dan perempuan dalam konteks proses berpikir dan pola kreatif melalui indikator keterampilan berpikir kreatif.

\section{Perbandingan Aspek Kelancaran (Fluency)}

Menurut (Al-Oweidi, 2013), aspek kelancaran merupakan kemampuan untuk memproduksi banyak ide. Berdasarkan pendapat tersebut, dapat dikatakan bahwa aspek kelancaran (fluency) berkaitan dengan kemampuan seseorang dalam memberikan banyak kemungkinan jawaban, ide, dan solusi terhadap suatu permasalahan yang diberikan. Berdasarkan penelitian yang telah dilakukan, terlihat pada Gambar 2 bahwa terdapat perbedaan grafik skor aspek kelancaran antara subjek laki-laki dan perempuan.

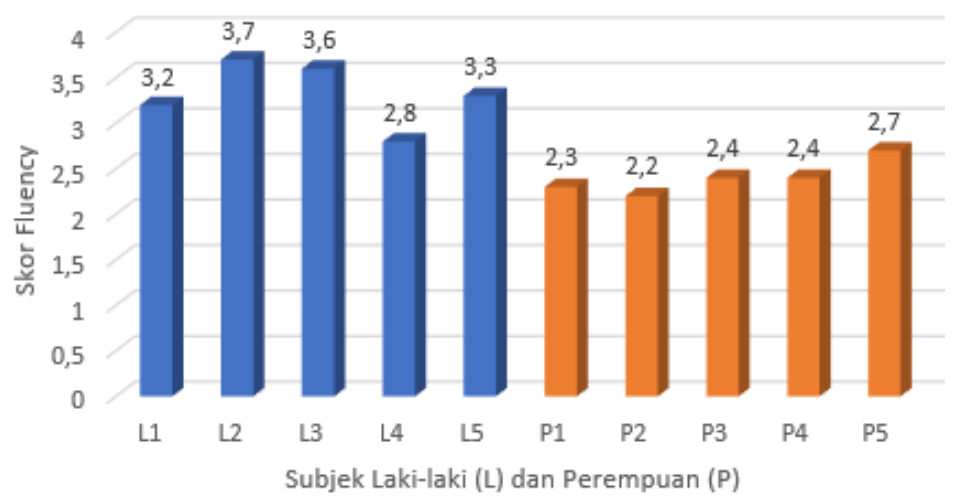

Gambar 2. Grafik Perbandingan Skor Keterampilan Berpikir Kreatif Aspek Kelancaran

Berdasarkan grafik pada Gambar 2, terlihat bahwa terdapat perbedaan skor ratarata antara subjek laki-laki (L1-L5) dan perempuan (P1-P5). Empat dari lima subjek laki-laki mendapatkan skor rata-rata lebih dari 3 untuk aspek kelancaran, sedangkan semua subjek perempuan mendapatkan skor rata-rata kurang dari 3. Data skor rata-rata aspek kelancaran dianalisis menggunakan uji-t dengan taraf signifikansi $5 \%$ disajikan pada Tabel 2 berikut.

Tabel 2. Hasil Analisis Uji-t terhadap Skor Rata-rata Aspek Kelancaran

\begin{tabular}{cll}
\hline No & Analisis & Nilai \\
\hline 1. & Mean $L$ & 3,32 \\
\hline 2. & Mean $P$ & 2,40 \\
\hline 3. & $\mathrm{t}_{\text {stat }}$ & 5,111111111 \\
\hline 4. & $\mathrm{t}_{\text {critical }}$ one-tail & 1,859548038 \\
\hline 5. & $\mathrm{P}(\mathrm{T}<=\mathrm{t})$ one-tail & 0,000458593
\end{tabular}

Hasil analisis uji-t terhadap skor ratarata aspek kelancaran antara subjek laki-laki dan perempuan memperlihatkan bahwa harga $t_{\text {hitung }}$ adalah sebesar 5,111111111. Harga $t_{\text {hitung }}$ lebih besar dibandingkan harga $t_{\text {tabel }}$ sebesar 1,859548038. Terlihat pula harga $\mathrm{P}(\mathrm{T}<=\mathrm{t})$ one-tail sebesar 0,000458593 lebih kecil dibandingkan taraf signifikansi yang 
diberikan, yakni 0,05 . Hasil tersebut menekankan bahwa terdapat perbedaan yang signifikan pada aspek kelancaran antara subjek laki-laki dan perempuan. Hasil tersebut memperlihatkan juga bahwa, meskipun tidak ada perbedaan yang signifikan pada karakteristik keterampilan berpikir kreatif secara umum antara subjek laki-laki dan perempuan, ternyata terdapat perbedaan pada aspek kelancaran yang tidak lain merupakan salah satu indikator keterampilan berpikir kreatif.

Perbedaan karakteristik aspek kelancaran antara subjek laki-laki dan perempuan terlihat pada cara menjawab permasalahan fisika yang diberikan. Mayoritas subjek laki-laki memberikan banyak kemungkinan jawaban yang berkaitan dengan permasalahan dan benar secara konsep fisika, sedangkan mayoritas subjek perempuan hanya memberikan $1-2$ kemungkinan jawaban saja. Sebagai contoh, terdapat soal tentang energi yang berkaitan dengan pembangkit listrik yang sesuai untuk dikembangkan di Indonesia, mayoritas subjek laki-laki memberikan $3-5$ alternatif jawaban, sedangkan subjek perempuan hanya memberikan $1-2$ alternatif jawaban tentang macam-macam pembangkit listrik. Perbedaan karakteristik tersebut sesuai dengan pendapat Abraham et.al (2013) yang mengatakan bahwa pada saat berpikir divergen, otak laki-laki lebih cenderung bekerja dengan menggunakan memori deklaratif dibandingkan dengan perempuan. Hal ini berarti otak laki-laki sangat aktif dalam menggunakan ingatan jangka panjang untuk mengeksplorasi pengetahuan dan fakta-fakta yang saling berhubungan, sehingga subjek laki-laki akan lebih mudah menuangkan banyak ide berdasarkan pengetahuan dan fakta-fakta yang saling berhubungan tersebut.

\section{Perbandingan Aspek Keluwesan (Flexibility)}

Aspek keluwesan (flexibility) berkaitan dengan kemampuan seseorang dalam memberikan jawaban, solusi, dan alternatif di luar jawaban pada umumnya. Dapat dikatakan bahwa orang yang memiliki aspek keluwesan yang tinggi mampu memberikan variasi jawaban yang out of the box namun tetap benar secara konsep. Berdasarkan penelitian yang telah dilakukan, terlihat pada Gambar 3 bahwa terdapat perbedaan grafik skor aspek keluwesan antara subjek laki-laki dan perempuan.

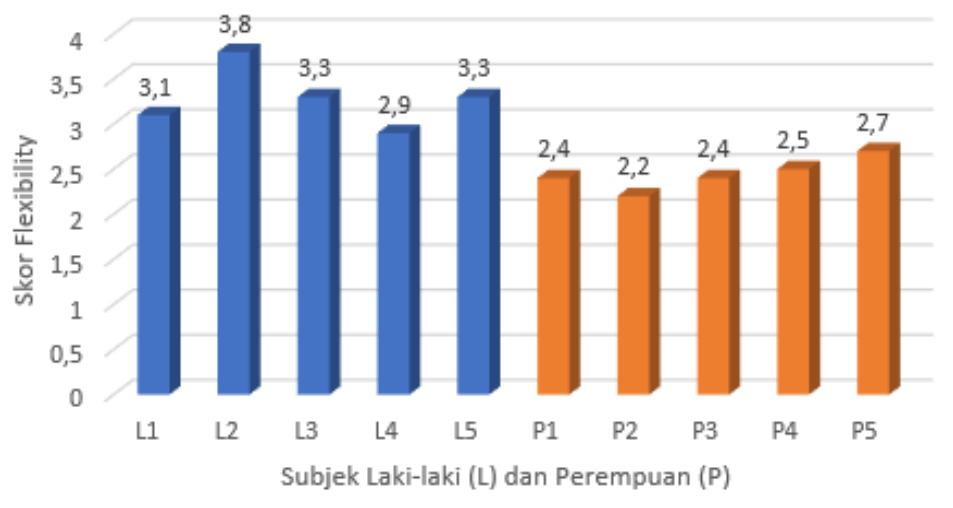

Gambar 3. Grafik Perbandingan Skor Keterampilan Berpikir Kreatif Aspek Keluwesan

Berdasarkan grafik pada Gambar 3, terlihat bahwa terdapat perbedaan skor ratarata antara subjek laki-laki (L1-L5) dan perempuan (P1-P5). Sama halnya dengan aspek kelancaran, pada aspek keluwesan terdapat empat subjek laki-laki mendapatkan skor rata-rata lebih dari 3 untuk aspek kelancaran, sedangkan semua subjek perempuan mendapatkan skor rata-rata kurang dari 3. Data skor rata-rata aspek keluwesan dianalisis menggunakan uji-t dengan taraf signifikansi $5 \%$ disajikan pada Tabel 3 berikut. 
Jurnal Pendidikan Fisika dan Keilmuan (JPFK), 4 (2), 2018 - 103

Mochammad Maulana Trianggono, Setyaningsih Yuanita

Tabel 3. Hasil Analisis Uji-t terhadap Skor Rata-rata Aspek Keluwesan

\begin{tabular}{cll}
\hline No & Analisis & Nilai \\
\hline 1. & Mean $L$ & 3,28 \\
\hline 2. & Mean $P$ & 2,44 \\
\hline 3. & $\mathrm{t}_{\text {stat }}$ & 4,932649844 \\
\hline 4. & $\mathrm{t}_{\text {critical }}$ one-tail & 1,859548038 \\
\hline 5. & $\mathrm{P}(\mathrm{T}<=\mathrm{t})$ one-tail & 0,000572805 \\
\hline
\end{tabular}

Hasil analisis uji-t terhadap skor ratarata aspek keluwesan antara subjek laki-laki dan perempuan memperlihatkan bahwa harga $t_{\text {hitung }}$ adalah sebesar 4,932649844. Harga $t_{\text {hitung }}$ lebih besar dibandingkan harga $t_{\text {tabel }}$ sebesar 1,859548038. Terlihat pula harga $\mathrm{P}(\mathrm{T}<=\mathrm{t})$ one-tail sebesar 0,000572805 lebih kecil dibandingkan taraf signifikansi yang diberikan, yakni 0,05 . Hasil tersebut menekankan bahwa terdapat perbedaan yang signifikan pada aspek keluwesan antara subjek laki-laki dan perempuan.

Pada dasarnya, aspek keluwesan juga berkaitan erat dengan aspek kelancaran pada proses berpikirnya. Semakin banyak ide atau alternatif jawaban yang diberikan untuk menjawab permasalahan, maka semakin dimunginkan terdapat variasi-variasi jawaban di luar jawaban pada umumnya (out of the box) yang masih tetap benar secara konseptual. Pada aspek kelancaran, terlihat bahwa mayoritas subjek laki-laki memberikan banyak ide atau alternatif jawaban terhadap permasalahan yang diberikan. Variasi-variasi jawaban yang diberikan berbeda dengan jawaban pada umumnya (kunci jawaban yang diberikan). Sebagai contoh, terdapat permasalahan kaca mobil yang berembun, banyak diantara subjek laki-laki yang memberikan penjelasan tentang proses pengembunan yang dilihat dari berbagai sudut pandang, ada pula yang memberikan alternatif solusi untuk mengurangi dampak pengembunan melalui berbagai macam cara. Subjek perempuan hanya mampu memberikan jawaban sesuai dengan jawaban pada umumnya (proses pengembunan dan solusinya).

\section{Perbandingan Aspek Orisinalitas (Originality)}

(Al-Oweidi, 2013)mengatakan bahwa aspek orisinalitas atau keaslian merupakan karakteristik yang paling tinggi dari kreativitas, karena aspek orisinalitas memerlukan kebaruan dan keunikan dalam menciptakan suatu produk pikiran yang inovatif. Berdasarkan pendapat tersebut, dapat dikatakan bahwa aspek orisinalitas (originality) berkaitan dengan kemampuan seseorang untuk memberikan ide atau gagasan yang inovatif dan unik. Inovatif berarti memiliki karakteristik kebaruan dan pembaharuan, artinya ide yang diungkapkan adalah ide yang benar-benar baru atau belum ada sebelumnya. Unik memiliki makna berbeda dengan lainnya, artinya ide yang diungkapkan adalah ide yang berbeda dengan kebanyakan orang/ tidak sama dengan pemikiran orang lain, namun masih dapat diterima dan tetap benar secara konsep. Berdasarkan penelitian yang telah dilakukan, terlihat pada Gambar 4 bahwa tidak terdapat perbedaan pada grafik skor aspek orisinalitas antara subjek laki-laki dan perempuan.

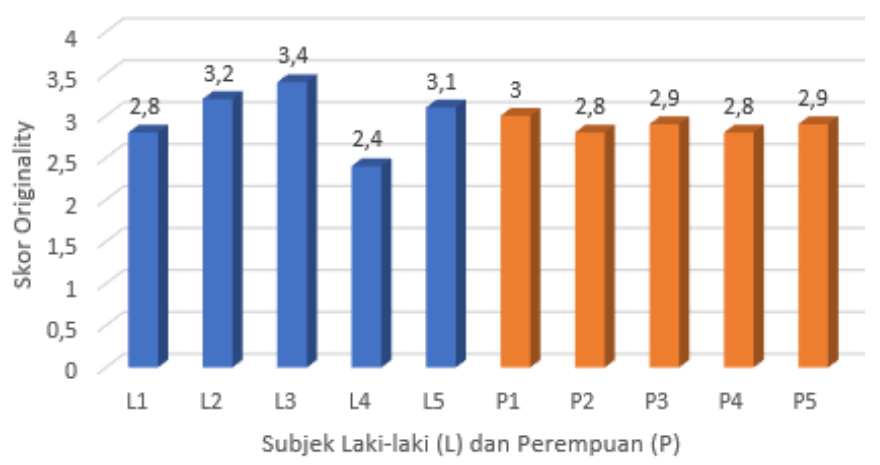

Gambar 4. Grafik Perbandingan Skor Keterampilan Berpikir Kreatif Aspek Orisinalitas 
Grafik pada Gambar 4 memperlihatkan bahwa skor rata-rata aspek orisinalitas antara subjek laki-laki dan perempuan tidak terdapat perbedaan yang terlalu jauh, atau dapat dikatakan sebanding. Data skor rata- rata aspek orisinalitas dianalisis menggunakan uji-t dengan taraf signifikansi 5\% disajikan pada Tabel 4 berikut.

Tabel 4. Hasil Analisis Uji-t terhadap Skor Rata-rata Aspek Orisinalitas

\begin{tabular}{cll}
\hline No & Analisis & Nilai \\
\hline 1. & Mean $L$ & 2,98 \\
\hline 2. & Mean $P$ & 2,88 \\
\hline 3. & $\mathrm{t}_{\text {stat }}$ & 0,560772154 \\
\hline 4. & $\mathrm{t}_{\text {critical }}$ one-tail & 1,859548038 \\
\hline 5. & $\mathrm{P}(\mathrm{T}<=\mathrm{t})$ one-tail & 0,295154355
\end{tabular}

Hasil analisis uji-t terhadap skor ratarata aspek orisinalitas antara subjek laki-laki dan perempuan memperlihatkan bahwa harga $t_{\text {hitung }}$ adalah sebesar 0,560772154. Harga $t_{\text {hitung }}$ lebih kecil dibandingkan harga $t_{\text {tabel }}$ sebesar 1,859548038. Terlihat pula harga $\mathrm{P}(\mathrm{T}<=\mathrm{t})$ one-tail sebesar 0,295154355 lebih besar dari taraf signifikansi yang diberikan, yakni 0,05. Hasil tersebut menekankan bahwa tidak terdapat perbedaan yang signifikan pada aspek orisinalitas antara subjek laki-laki dan perempuan.

Aspek orisinalitas sangat sulit muncul dan dikembangkan, karena pada aspek orisinalitas harus memiliki karakter yang kuat untuk berbeda dengan lainnya. Aspek orisinalitas juga sangat sulit dinilai karena belum tentu jawaban yang diberikan tersebut merupakan suatu kebaruan atau sesuatu hal yang baru, sehingga dalam penilaian, yang dijadikan tolak ukur adalah dari sisi keunikan jawaban saja. Keunikan tersebut dinilai berdasarkan jawaban yang diberikan oleh salah satu subjek dibandingkan dengan jawaban-jawaban subjek lainnya. Jika jawaban tersebut berbeda sama sekali dengan jawaban subjek lainnya (namun masih tetap benar secara konsep), maka skor orisinalitas yang didapatkan juga semakin tinggi. Berdasarkan jawaban-jawaban pada tes pemecahan fisika yang telah dilakukan, terlihat hanya beberapa jawaban saja yang dinilai sebagai keunikan, meskipun ada beberapa bagian jawaban yang mirip. Baik subjek laki-laki maupun perempuan memiliki kecenderungan yang sama dalam hal orisinalitas.

\section{Perbandingan Aspek Elaborasi (Elaboration) \\ Aspek elaborasi (elaboration)} berkaitan dengan kemampuan seseorang dalam mentransformasikan ide atau gagasan dalam suatu bentuk perincian yang detail. Aspek elaborasi memerlukan kemampuan untuk merinci dan membuat detail dari rincian tersebut. Berdasarkan penelitian yang telah dilakukan, terlihat pada Gambar 5 bahwa terdapat perbedaan pada grafik skor aspek elaborasi antara subjek laki-laki dan perempuan.

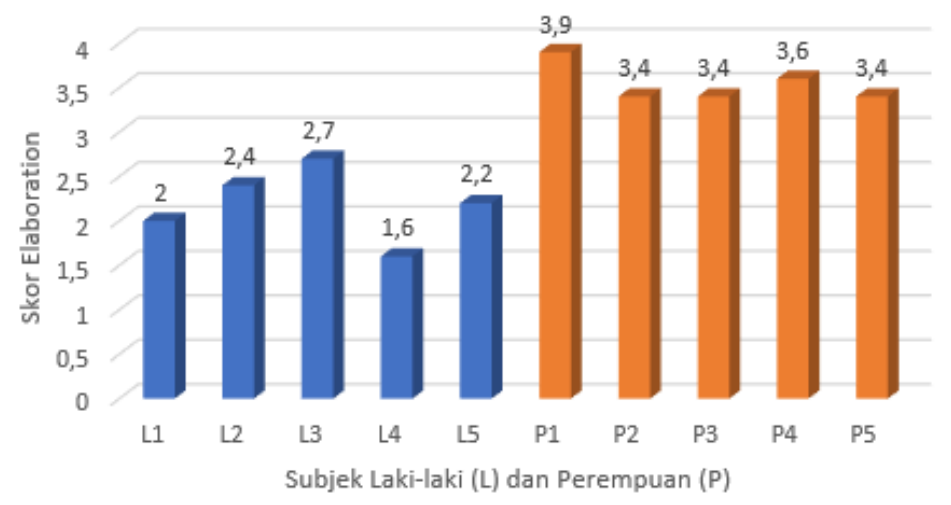

Gambar 5. Grafik Perbandingan Skor Keterampilan Berpikir Kreatif Aspek Elaborasi

Grafik pada Gambar 5 memperlihatkan bahwa skor rata-rata aspek elaboasi antara subjek laki-laki dan perempuan terdapat perbedaan yang signifikan. Terlihat bahwa 
semua subjek laki-laki memiliki skor ratarata di bawah 3, sedangkan semua subjek perempuan memiliki skor rata-rata di atas 3 . Data skor rata-rata aspek orisinalitas dianalisis menggunakan uji-t dengan taraf signifikansi $5 \%$ disajikan pada Tabel 5 berikut.

Tabel 5. Hasil Analisis Uji-t terhadap Skor Rata-rata Aspek Elaborasi

\begin{tabular}{cll}
\hline No & Analisis & Nilai \\
\hline 1. & Mean $L$ & 2,18 \\
\hline 2. & Mean $P$ & 3,54 \\
\hline 3. & $\mathrm{t}_{\text {stat }}$ & 6,483545607 \\
\hline 4. & $\mathrm{t}_{\text {critical }}$ one-tail & 1,859548038 \\
\hline 5. & $\mathrm{P}(\mathrm{T}<=\mathrm{t})$ one-tail & 0,000095698
\end{tabular}

Hasil analisis uji-t terhadap skor ratarata aspek elaborasi antara subjek laki-laki dan perempuan memperlihatkan bahwa harga $t_{\text {hitung }}$ adalah sebesar 6,483545607. Harga $t_{\text {hitung }}$ lebih besar dibandingkan harga $t_{\text {tabel }}$ sebesar 1,859548038. Terlihat pula harga $\mathrm{P}(\mathrm{T}<=\mathrm{t})$ one-tail sebesar 0,000095698 lebih kecil dibandingkan taraf signifikansi yang diberikan, yakni 0,05. Hasil tersebut menekankan bahwa terdapat perbedaan yang signifikan pada aspek elaborasi antara subjek laki-laki dan perempuan.

Aspek elaborasi memungkinkan seseorang untuk menambahkan detail dari jawaban yang diberikan. Berdasarkan mean score antara subjek laki-laki dan perempuan, terlihat bahwa subjek perempuan memiliki mean score yang lebih tinggi dibandingkan laki-laki pada aspek elaborasi. Hal ini terjadi karena pada observasi terhadap pola jawaban yang diberikan pada saat tes pemecahan masalah, meskipun mayoritas subjek perempuan hanya memberikan 1-2 alternatif jawaban/solusi, subjek perempuan selalu memberikan jawaban yang panjang dan detail. Subjek laki-laki memberikan banyak alternatif jawaban, tetapi tidak memberikan rincian terhadap jawaban tersebut secara detail, sehingga nilai pada aspek elaborasinya rendah. Sebagai contoh, pada permasalahan aplikasi solar cell pada rumah, subjek lakilaki hanya menggambarkan desain aplikasi solar cell pada rumah tanpa memberikan detail-detail khusus untuk menjabarkan gambar tersebut, sedangkan subjek perempuan memberikan gambar aplikasi solar cell lengkap dengan atribut-atribut yang menyertainya, serta menambahkan detail-detail khusus pada setiap bagian gambar. Hasil tersebut sejalan dengan pendapat Abraham et.al (2013) yang menyatakan bahwa pada saat menggunakan pikiran kreatifnya, perempuan lebih banyak menggunakan daerah dalam otak yang terlibat dalam teori pikiran dan proses referensi. Berdasarkan pendapat tersebut, dapat dimungkinkan bahwa proses referensi mendukung terciptanya pemikiran untuk membuat detail-detail dari rincian jawaban yang diberikan.

\section{KESIMPULAN}

Secara umum dapat dikatakan bahwa, setiap orang memiliki potensi kreatif yang berbeda-beda, baik dari sudut pandang maupun dari karakteristik berpikir kreatif yang dimilikinya. Keterampilan berpikir kreatif seseorang dipengaruhi oleh karakteristik pribadi, karakter permasalahan, dan sudut pandang. Seseorang dapat mengembangkan potensi kreatif yang ada pada dirinya dengan mengenal terlebih dahulu karakteristik keterampilan berpikir kreatif apa yang menonjol padanya.

Laki-laki dan perempuan secara umum memiliki karakteristik berpikir kreatif yang sebanding, namun secara khusus memiliki perbedaan di berbagai aspek keterampilan berpikir kreatifnya. Laki-laki unggul pada aspek tertentu, sedangkan perempuan juga unggul di aspek yang lainnya. Masingmasing individu memiliki potensi yang sama untuk berkembang, sehingga perlu adanya suatu bentuk pembelajaran yang komperhensif sebagai wadah untuk mengasah keterampilan berpikir kreatif yang dimilikinya. 


\section{DAFTAR PUSTAKA}

Abraham, A. (2016). Gender and creativity: an overview of psychological and neuroscientific literature. Brain Imaging and Behavior, 10(2), 609-618. https://doi.org/10.1007/s11682-0159410-8

Abraham, A., Thybusch, K., Pieritz, K., \& Hermann, C. (2014). Gender differences in creative thinking: behavioral and fMRI findings. Brain Imaging and Behavior, 8, 39-51. https://doi.org/10.1007/s11682-0139241-4

Ai, X. (1999). Creativity and Academic Achievement: An Investigation of Gender Differences. Creativity Research Journal, 12(4), 329-337. https://doi.org/10.1207/s15326934crj12 04

Al-Oweidi, A. (2013). Creative Characteristics and Its Relation to Achievement and School Type among Jordanian Students, 4(1), 29-34. https://doi.org/10.4236/ce.2013.41004
Djupanda, H., Kendek, Y., \& Darmadi, I. W. (2015). Analisis Keterampilan Berpikir Kreatif Siswa Sma Dalam Memecahkan Masalah Fisika. Jurnal Pendidikan Fisika Tadulako (JPFT), 3(2), 3-8.

Guilford, J. P. (1967). The nature of human intelligence. New York: McGraw-Hill.

Naderi, H., Abdullah, R., Aizan, H. T., Sharir, J., \& Mallan, V. K. (2009). Gender Differences in Creative Perceptions of Undergraduate Students. Journal of Applied Sciences, 9(1), 167172. https://doi.org/10.3923/jas.2009.167.17 2

Trianggono, M. M. (2017). Analisis Kausalitas Pemahaman Konsep Dengan Kemampuan Berpikir Kreatif Siswa Pada Pemecahan Masalah Fisika. Jurnal Pendidikan Fisika Dan Keilmuan (JPFK), 3(1), 1. https://doi.org/10.25273/jpfk.v3i1.874 